\title{
Comparison of radial haemolysis with haemagglutination inhibition in estimating rubella antibody
}

\author{
P. N. APPLETON AND A. D. MACRAE \\ From the Public Health Laboratory, City and Sherwood Hospitals, Nottingham NG5 1PH, UK
}

SUMMARY Radial haemolysis (RH) for assaying rubella antibody was studied in parallel tests with haemagglutination-inhibition (HAI) on 1102 sera from adult women. Simple to perform and economical in reagents, the RH test is as sensitive as the HAI test and is a useful method of screening antenatal and other sera for rubella immunity. It detects IgG but not IgM antibody.

Rubella antibody tests provide much of the work in clinical virus laboratories. The method commonly used is the haemagglutination inhibition (HAI) test. Although sensitive and specific, this test requires that sera must first be treated to remove non-specific (NS) inhibitors. Removal may be incomplete, and sometimes part of the rubella-specific antibody may also be removed (Mann et al., 1967; Plotkin, 1969). A rapid, simple assay method not subject to interference by NS inhibitor would therefore be advantageous.

A radial haemolysis $(\mathrm{RH})$ technique for measuring influenza and rubella antibodies that requires only preliminary heat inactivation of serum has been reported (Russell et al., 1975; Skaug et al., 1975; Strannegård et al., 1975). We have studied its efficacy for everyday use as an alternative to the HAI test. RH and HAI tests for rubella antibody were done in parallel on 1102 sera received mainly from pregnant women.

\section{Material and methods}

The rubella haemagglutinin used was lyophilised rubella haemagglutinin (Standards Laboratory, Central Public Health Laboratory, Colindale) with a titre of 1:256 against day-old chick erythrocytes.

Dextrose-gelatin-veronal buffer with $0.02 \%$ bovine plasma albumin pH 7.5 (DGV-BPA) was used as diluent for the HAI test (diluent 1), and veronalbuffered saline pH 7.2 (CFTD/Oxoid) for the RH test (diluent 2).

For agarose we used Indubiose A37 (l'Industrie

Received for publication 24 October 1977
Biologique Française) $1.5 \%$ in diluent 2 containing $0.02 \%$ sodium azide. Agarose (Miles Laboratories) used in the same concentration was also satisfactory.

Chick erythrocytes were from blood withdrawn into Alsever's solution from day-old unfed male chicks and stored for up to 14 days at $4^{\circ} \mathrm{C}$. Cells were washed three times before use and resuspended to the required concentration in the appropriate diluent.

The complement was lyophilised guinea-pig serum (LIP Ltd) reconstituted in distilled water immediately before use.

\section{HAI TEST}

\section{Removal of NS inhibitor}

Sera were diluted 1:5 in a solution composed of one part $1 \mathrm{M} \mathrm{MnCl}$, one part heparin $(5000 \mathrm{U} / \mathrm{ml})$, and four parts diluent 1 . Diluted sera were held at $4^{\circ} \mathrm{C}$ for 20 minutes, then centrifuged at $1500 \mathrm{~g}$ for 20 minutes. The supernatant fluid was removed for the next part of the test.

\section{Test}

A standard volume of $0.025 \mathrm{ml}$ was used. Doubling dilutions of sera were made in 96 well (U-shaped) microplates ranging from 1:10 to 1:5120. A 1:10 dilution as serum control was included. Haemagglutinin (4 units) was added to each test well. Plates were shaken and the mixtures left at room temperature for one hour. Washed chick erythrocytes $(0.3 \%$ in diluent 1) were then added; plates were again shaken and held at $4^{\circ} \mathrm{C}$ for about $1 \frac{1}{2}$ hours until the cells had settled. At this stage results were recorded. 
Erythrocytes 7-14 days old gave the most reproducible zones of haemolysis. Fresh cells were found to be more resistant to lysis and those older than 14 days tended to lyse spontaneously in agarose.

For antigen-coated cells $4 \mathrm{ml} \mathrm{1:2}$ dilution of reconstituted rubella haemagglutinin was mixed with $4 \mathrm{ml} \mathrm{10 \%}$ washed chick erythrocyte suspension.

Control cells were $8 \mathrm{ml}$ of $5 \%$ washed chick erythrocyte suspension.

Both preparations were held at $4^{\circ} \mathrm{C}$ for 30 minutes, then centrifuged at $1000 \mathrm{~g}$ for two minutes. Supernatant fluids were discarded and each cell deposit was resuspended in $8 \mathrm{ml}$ diluent.

\section{Preparation of test and control agarose-erythrocyte mixtures}

Each erythrocyte suspension was gently mixed in 67 $\mathrm{ml}$ molten agarose previously cooled to about $50^{\circ} \mathrm{C}$.

\section{Preparation of plates}

Clean, unscratched microplate lids were suitable, a level surface being essential. Aliquots of $15 \mathrm{ml}$ agarose-erythrocyte mixture per lid were poured and allowed to set (plates may be stored in a moist box at $4^{\circ} \mathrm{C}$ for up to a week). The five test and control plates thus prepared were sufficient for testing 250 sera.

Within the area of a plate $(12.7 \times 8.3 \mathrm{~cm}) 54$ wells $3 \mathrm{~mm}$ in diameter were cut equidistant from the edges and from each other by placing the plate over a marked paper template, the spots indicating the centres of the wells being visible through the agarose. A sharp-edged metal cutter of suitable diameter and slightly bevelled internally was used. Agarose plugs were then removed by means of a Pasteur pipette connected to suction apparatus. Plates with cut wells were flooded with complement at 1:10 dilution and held at $4^{\circ} \mathrm{C}$ for at least one hour. Excess fluid was then removed, the wells again being cleared with a Pasteur pipette as before.

Sera to be tested were inactivated at $56^{\circ} \mathrm{C}$ for 30 minutes and allowed to cool. Aliquots of each sample were placed in corresponding wells of test and control plates. To obtain reproducible zone sizes it was essential to fill the wells to the level of the agarose surface. This was done most satisfactorily with disposable microcapillary tubes (Hawksley Microhaematocrit). Plates were then held in a moist environment for 18 hours at $4^{\circ} \mathrm{C}$ to allow diffusion of antibody before incubating at $37^{\circ} \mathrm{C}$ for two hours, during which time haemolysis took place.

Zone diameters were measured to the nearest $0 \cdot 1$ $\mathrm{mm}$ with a magnifying calibrated zone reader (Transidyne/Dynatech).

CONTROL SERA

For each HAI test sera with previously estimated titres of 1 in 640,1 in 20 , and $<1$ in 20 respectivel产 were included.

For the RH tests a serum with an HAI titre of 1 i 640 was diluted in known negative serum to 1 in $2, \Phi$ in 8,1 in 32 , and 1 in 128 . These serum dilutions? representing HAI titres of 1 in 320,1 in 80,1 in $2 \%$ and 1 in 5 respectively, were distributed throughou different plates in random fashion.

\section{Results}

It was essential to establish the reproducibility of the RH test.

The four control sera were each tested 13 times ib the same plate. The correlation between HAI titres and the size and reproducibility of all the zones of haemolysis is shown in Table 1.

Table 1 Reproducibility of radial haemolysis zone diameters on a single plate

\begin{tabular}{llll}
\hline $\begin{array}{l}\text { Serum HAI } \\
\text { titre }\end{array}$ & Serum dilution & $\begin{array}{l}\text { Mean } Z D^{*} \\
( \pm 1 S D)\end{array}$ & $\begin{array}{l}\text { Coefficient of } \\
\text { variation } \\
(13\end{array}$ \\
& & determinations $)$ \\
\hline 5 & $1: 128$ & $4 \cdot 00 \pm 0 \cdot 14$ & $3 \cdot 50$ \\
20 & $1: 32$ & $6 \cdot 45 \pm 0 \cdot 20$ & $3 \cdot 10$ \\
80 & $1: 8$ & $9 \cdot 65 \pm 0 \cdot 18$ & $1 \cdot 87$ \\
320 & $1: 2$ & $11 \cdot 73 \pm 0.26$ & $2 \cdot 22$ \\
\hline
\end{tabular}

*Zone diameter (mm)

Within a batch of five plates prepared on a single occasion the four control sera were each tested i⿳⺈ duplicate in a single plate on five successive days The results are shown in Table 2. The zones of haemolysis did not vary unduly and retained thei correlation with the HAI titres.

When tested in plates from different batches the four control sera showed variations up to $1 \mathrm{~mm}$. the zone diamaters obtained. However, plotting the zone diameter against $\log _{2}$ of the reciprocal of the HAI titre always gave a straight line of similar slopos as shown in Figure 1. These tests also indicated that antibody equivalent to an HAI titre of 1 in 5 couf be reliably detected by radial haemolysis, as shown in Fig. 1. In practice, however, positive sera showed zone diameter of haemolysis equivalent to or greater than the control serum, which had an HAI titre of in 20.

From tests on serum fractions collected in the course of sucrose density gradient centrifugation on 7 those fractions containing rubella-specific IgG an body gave zones of haemolysis in the RH tesf. Haemolysis was not observed in the presence rubella specific IgM antibody (fractions 2-4) or 
Table 2 Reproducibility of radial haemolysis zone diameters in plates from same batch used over five days

\begin{tabular}{|c|c|c|c|c|c|c|c|c|}
\hline \multirow[t]{2}{*}{ Serum HAI titre } & \multicolumn{6}{|l|}{ Day } & \multirow[t]{2}{*}{ Mean $Z D( \pm I S D)$} & \multirow{2}{*}{$\begin{array}{l}\text { Coefficient } \\
\text { of } \\
\text { variation }\end{array}$} \\
\hline & & 1 & 2 & 3 & 4 & 5 & & \\
\hline \multirow[t]{2}{*}{5} & (a) & 3.6* & 3.9 & $4 \cdot 3$ & $3 \cdot 6$ & $4 \cdot 1$ & & \\
\hline & (b) & 3.9 & $3 \cdot 6$ & $4 \cdot 0$ & $4 \cdot 0$ & $4 \cdot 2$ & $3.92 \pm 0.25$ & $6 \cdot 38$ \\
\hline \multirow[t]{2}{*}{20} & (a) & $6 \cdot 2$ & $6 \cdot 5$ & $6 \cdot 3$ & $6 \cdot 2$ & 6.6 & & \\
\hline & (b) & $6 \cdot 5$ & $7 \cdot 0$ & $6 \cdot 3$ & $6 \cdot 7$ & $6 \cdot 8$ & $6.51 \pm 0.27$ & $4 \cdot 15$ \\
\hline \multirow[t]{2}{*}{80} & (a) & $9 \cdot 6$ & $9 \cdot 3$ & $9 \cdot 7$ & $9 \cdot 4$ & $9 \cdot 6$ & & \\
\hline & (b) & $9 \cdot 6$ & $9 \cdot 2$ & $9 \cdot 5$ & $9 \cdot 3$ & $9 \cdot 1$ & $9 \cdot 48 \pm 0.25$ & $2 \cdot 64$ \\
\hline \multirow[t]{2}{*}{320} & (a) & $12 \cdot 0$ & $11 \cdot 6$ & $11 \cdot 3$ & $12 \cdot 0$ & $12 \cdot 1$ & & \\
\hline & (b) & $11 \cdot 7$ & $12 \cdot 1$ & $11 \cdot 9$ & $11 \cdot 4$ & $12 \cdot 4$ & $11 \cdot 80 \pm 0.37$ & $3 \cdot 14$ \\
\hline
\end{tabular}

*Zone diameter (mm)

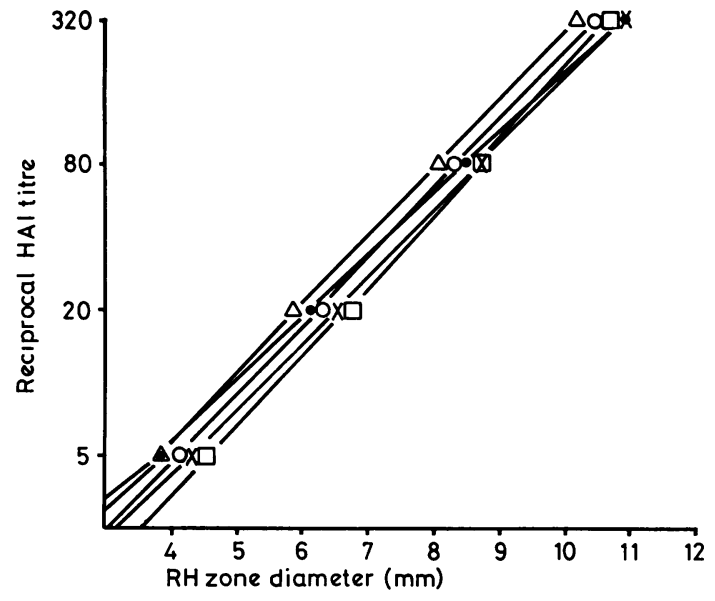

Fig. 1 Comparative tests with four control sera. Symbols $\triangle, \bigcirc, \bigcirc, \times, \square$ show results from five plates from different batches.

non-specific IgG or inhibitor (fractions 11, 12) (Fig. 2).

As shown in Table 3, a total of 1102 sera were then compared. In a representative run of 100 tests only one serum showed divergent results (Fig. 3). It had a high titre by haemagglutination inhibition with no zone by radial haemolysis. The inhibitor was not present in IgM or IgG fractions but in those from the top of a sucrose density gradient column.

The serum was turbid and microscopy revealed Gram-negative bacilli, though aerobic and anaerobic bacterial culture were negative. Inhibitor in contaminated serum has been reported (Bruce White and Tinnion, 1975). Chick erythrocyte agglutinins were found in 22 sera but none of these caused lysis in the control RH plates. Two sera showed unexplained lysis in control plates with zone diameters of 4.2 and $5.4 \mathrm{~mm}$. In the test plate, however, the respective zone diameters were $\mathbf{7 . 9}$ and $11.2 \mathrm{~mm}$, which con-

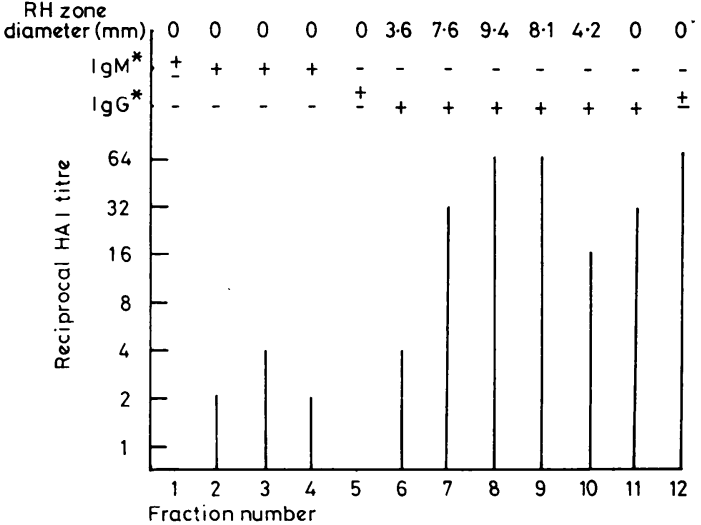

Fig. 2 Comparison of $\mathrm{RH}$ and $\mathrm{HAI}$ on density gradient serum fractions. ${ }^{*} \operatorname{IgM}$ and $\operatorname{IgG}$ detected by gel precipitation with monospecific antisera.

Table 3 Comparison of HAI titres and radial haemolysis zone diameters in 1102 sera

\begin{tabular}{|c|c|c|c|}
\hline HAI titre & No. $(\%)$ & $\begin{array}{l}\operatorname{Mean} Z D^{*} \\
( \pm I S D)\end{array}$ & $\begin{array}{l}\text { Coefficient of } \\
\text { variation }\end{array}$ \\
\hline $\begin{array}{r}20 \\
20 \\
40 \\
80 \\
160 \\
320 \\
640 \\
1280 \\
2560 \\
\text { Total }\end{array}$ & $\begin{array}{r}166(15 \cdot 1) \\
34(3 \cdot 1) \\
119(10 \cdot 8) \\
217(19 \cdot 7) \\
278(25 \cdot 2) \\
204(18 \cdot 5) \\
63(5 \cdot 7) \\
16(1 \cdot 4) \\
5(0 \cdot 5) \\
1102(100)\end{array}$ & $\begin{array}{r}8.42 \pm 0.62 \\
9.41 \pm 0.73 \\
9.87 \pm 0.71 \\
10.61 \pm 0.80 \\
11.29 \pm 0.73 \\
11.82 \pm 0.88 \\
12.80 \pm 0.80 \\
13.13 \pm 1.04\end{array}$ & $\begin{array}{l}7 \cdot 36 \\
7 \cdot 76 \\
7 \cdot 19 \\
7 \cdot 54 \\
6 \cdot 47 \\
7 \cdot 45 \\
6 \cdot 25 \\
7 \cdot 92\end{array}$ \\
\hline
\end{tabular}

*Zone diamater (mm)

curred with the recorded HAI titres of 1 in 80 and 1 in 320 .

Not included in Table 3 were seven sera that had similar haemolysis zone diameters in both test and control plates. Four sera had HAI titres of 1 in 10 with zone diameters ranging from 3.8 to $4.7 \mathrm{~mm}$, 


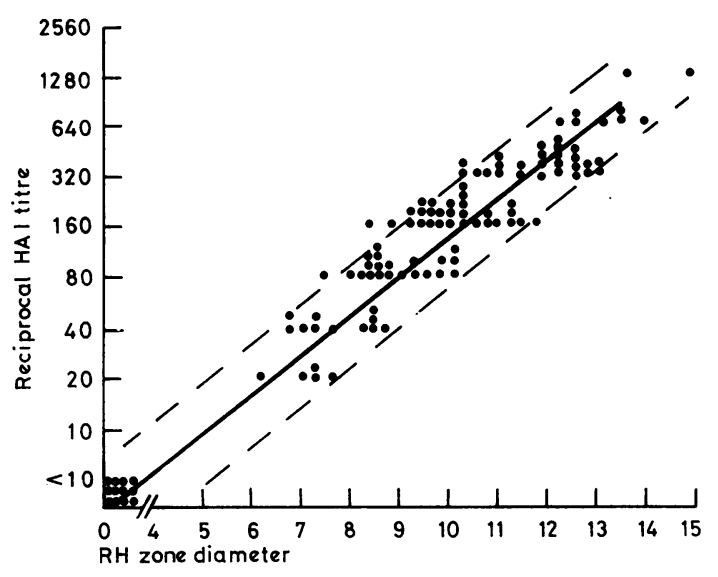

Fig. 3 Comparative tests by RH and HAI on 100 sera

three sera had HAI titres of 1 in 40 with zone diameters ranging from 7.7 to $9.2 \mathrm{~mm}$. None of these sera contained chick erythrocyte agglutinins.

\section{Discussion}

The radial haemolysis test detects antibody that reacts with antigen adhering to the erythrocyte surface. Lysis of such cells is due to complement activated by the bound antibody. In the test only the IgG antibody is detected. For some reason IgM antibodies, whether to rubella or to chick erythrocytes, do not cause lysis. This is in contrast to other haemolytic plaque assays, in which IgM but not IgG antibody induces lysis (Jerne and Nordin, 1963). The size of the zone of haemolysis varies with the amount of HAI antibody present. Straight line correlations between $\log _{2}$ of the reciprocal HAI titres and diameters of the zone of haemolysis have been obtained.

The RH test offers practical advantages over HAI. The serum can be tested undiluted and needs only prior heat inactivation to remove complement and any heat-labile substances that may lyse chick erythrocytes. From comparison with the control plates, essential in every test, results are evidently not altered by the presence of non-specific serum inhibitors or of chick erythrocyte agglutinins. Even the haemagglutinin inhibitor in a bacterially contaminated sample did not affect the RH test.
Zones of haemolysis corresponding to HAI titres of less than 1 in 20 were not observed in practice: Such low HAI titres, when found, are difficult to $\overrightarrow{\vec{s}}$ reproduce and probably lack specificity. There iso support for this in the results from the RH test, though the test itself was sufficiently sensitive to pick up antibody equivalent to an HAI titre of 1 in 5 ind the dilutions of the control serum.

The reproducibility of the RH test was affected by three factors. The complement had to soak into the agarose before serum was introduced into the wells $\overrightarrow{\vec{H}}$ If added afterwards a 'target' effect developed with as ring of lysed cells at the perimeter of the zone andi virtually intact cells around the well. Also with lowit titred sera the zone of lysis was faint and variable ${ }_{\text {ir }}$ The wells had to be filled with serum to the level of the agar surface. For this disposable microcapillarys tubes were preferable to a microlitre pipette. Someo batches of agarose caused spontaneous lysis of day old chick erythrocytes on storage of newly prepared plates. It was necessary therefore to ensure that the agarose to be used had been checked for suitability. $\overrightarrow{0}$

\section{References}

Bruce White, G. B., and Tinnion, K. H. (1975). A non specific inhibitor of rubella haemagglutinin (Letter)? Lancet, 2, 664.

Jerne, N. K., and Nordin, A. A. (1963). Plaque formation in agar by single antibody-producing cells. Science, 140, 405.

Mann, J. J., Rossen, R. D., Lehrich, J. R., and Kasel, J. A (1967). The effect of kaolin on immunoglobulins? Journal of Immunology, 98, 1136-1142.

Plotkin, S. A. (1969). Rubella virus. In Diagnostie Procedures for Viral and Rickettsial Infections, edited bj E. H. Lennette and N. J. Schmidt, 4th edition, p. 394 American Public Health Association, Inc., New York

Russell, S. M., McCahon, D., and Beare, A. S. (1975). single radial haemolysis technique for the measuremen of influenza antibody. Journal of General Virology, 27 1-10.

Skaug, K., Ørstavik, I., and Ulstrup, J. C. (1975) Application of the passive haemolysis test for the deter mination of rubella virus antibodies. Acta Pathologicd et Microbiologica Scandinavica, 83B, 367-372.

Strannegård, Ö., Grillner, L., and Lindberg, I-M. (1975) Haemolysis-in-gel test for the demonstration of antil bodies to rubella virus. Journal of Clinical Microbiology 1, 491-494. 